\title{
The Membrane Proximal Region of AMPA Receptors in Lateral Amygdala is Essential for Fear Memory Formation
}

\author{
Dan A Ganea', Monica Dines', Sreetama Basu' and Raphael Lamprecht*, \\ 'Sagol Department of Neurobiology, Faculty of Natural Sciences, University of Haifa, Haifa, Israel
}

\begin{abstract}
The membrane proximal region (MPR) of AMPA receptor (AMPAR) is needed for receptor trafficking and synaptic plasticity. However, its roles in long-term memory formation are not known. To assess the possible roles of AMPAR-MPR in rat lateral amygdala (LA) in shortand long-term fear memory formation, we used glutamate receptors (GluAs)-MPR competitive peptides MPR(DD) and MPR(AA). The MPR(DD) peptide is derived from GluAI MPR and was previously shown to impair synaptic plasticity and to inhibit GluAI containing AMPAR insertion into the synapse in an activity-dependent manner. The MPR(AA) peptide is derived from GluA2/4 MPR, and this receptor fragment was shown to be essential for GluA4 protein interaction needed for its insertion into the neuronal membrane and synapse. The peptides were linked to a TAT peptide (TAT-MPR(DD) and TAT-MPR(AA)) to facilitate internalization into LA cells. Infusion of the TAT-MPR(DD) peptide into LA 30 min before fear conditioning led to a significant impairment of long-term fear memory formation. Injection of TAT-MPR(DD) peptide into LA 30 min before fear conditioning impaired short-term fear memory formation. The TAT-MPR(DD) peptide had no effect on memory retrieval when injected into LA 30 min before fear memory test. Infusion of the TAT-MPR(AA) peptide into LA 30 min before fear conditioning led to a significant impairment of long-term fear memory formation. In contrast, the TAT-MPR(AA) had no effect on short-term fear memory formation. A TAT-control peptide had no effect on short- or longterm fear memory. These results show that the AMPAR-MPR in LA is needed for fear memory formation and that the MPR region of GluAI is essential for acquisition of memory, whereas the MPR region of GluA4 is essential for long-term fear memory consolidation. Neuropsychopharmacology (2015) 40, 2727-2735; doi:10.1038/npp.2015.I21; published online 20 May 2015
\end{abstract}

\section{INTRODUCTION}

The membrane proximal region (MPR) of AMPAR is comprised of 14 amino acids at the cytoplasmic tail immediately after the last membrane-spanning region and was shown to be involved in activity-dependent AMPAR synaptic trafficking (Boehm et al, 2006). In the GluA1 subunit, this region contains a PKC phosphorylation site (S818) that is being phosphorylated during long-term potentiation (LTP) and is critical for its insertion into the synapse and for synaptic plasticity (LTP) (Boehm et al, 2006). In GluA4, but not GluA2, alterations of alanine to serine at positions 816 and 818 in the MPR impaired receptor incorporation into synapses in slices with spontaneous neural activity (Boehm et al, 2006). In addition, GluA4-MPR was also shown to be needed for insertion of the receptor into hippocampal neurons surface (Coleman et al, 2003). GluA2-MPR region is not sufficient for the continuous delivery of GluA2 into the synapse and for protein interactions needed for its removal from the synapse (Shi et al, 2001; Lee et al, 2002; Boehm et al, 2006). GluA1 and

\footnotetext{
*Correspondence: Dr R Lamprecht, Sagol Department of Neurobiology, Faculty of Natural Sciences, University of Haifa, Mount Carmel, Haifa 31905, Israel, Tel: +972 4828 8786, Fax: +972 48240339 , E-mail: rlamp@research.haifa.ac.il

Received 14 November 2014; revised 16 March 2015; accepted 17 April 2015; accepted article preview online 27 April 2015
}

GluA4 containing AMPAR trafficking is mediated by interaction of GluA1-MPR and GluA4-MPR with intracellular proteins, such as protein $4.1 \mathrm{~N}$ and $\mathrm{PKC} \gamma$ (Shen et al, 2000; Coleman et al, 2003; Correia et al, 2003; Chen et al, 2005; Gomes et al, 2007; Lin et al, 2009). However, of note a recent study has shown that the MPR of GluA1 is not needed for protein trafficking or LTP in hippocampal CA1 (Granger et al, 2013).

In the present study, we were interested to elucidate whether AMPAR-MPR is needed for memory formation. Toward that end, we used the fear conditioning paradigm where an association is formed between a neutral tone conditioned stimulus (CS) and an aversive mild footshock unconditioned stimulus (US) (Fanselow and LeDoux, 1999; LeDoux, 2000; Davis and Whalen, 2001; Sah et al, 2003; Maren, 2005). The putative site of fear conditioning memory, the lateral nucleus of the amygdala (LA), has been identified (Fanselow and LeDoux, 1999; Schafe et al, 2001; Rodrigues et al, 2004; Maren, 2005; Johansen et al, 2011). GluA1-4 subunits proteins are detected in the LA of adult rats (Farb et al, 1995; Radley et al, 2007). It has been shown that fear conditioning drives GluA1-containing AMPARs into synapses in LA neurons and increases their level (Rumpel et al, 2005; Yeh et al, 2006; Nedelescu et al, 2010; Ota et al, 2010). Moreover, fear conditioning is impaired if GluA1AMPAR insertion is blocked (Rumpel et al, 2005). 
With the aim of studying the roles of MPR cytoplasmic site of AMPAR in LA in fear memory formation, we used wellestablished MPR-competing protein fragments (MPR(DD) and MPR(AA)) (Boehm et al, 2006; Correia et al, 2003; Gomes et al, 2007; Mitsushima et al, 2011) conjugated to TAT to facilitate their delivery into cells (TAT-MPR(DD) and TAT-MPR(AA)) (Schwarze et al, 1999). The MPR(DD) is derived from the GluA1 MPR site with serines (S816, S818) mutated to phospho-mimicking aspartates. Neurons expressing the MPR(DD) fragment are impaired in synaptic plasticity (LTP; Boehm et al, 2006) and in activitydependent synaptic AMPAR delivery in CA1 neurons (Mitsushima et al, 2011) but not in basal AMPAR- and NMDAR-mediated transmission (Boehm et al, 2006; Mitsushima et al, 2011). Studies have shown that the MPR (AA) protein fragment binds $\mathrm{PKC} \gamma$ or 4.1 protein and is needed for the insertion of GluA4 into synapse and neuronal membrane (Correia et al, 2003; Coleman et al, 2003; Gomes et al, 2007). We microinjected the MPR(AA) or MPR(DD) competitive peptides into LA to study the involvement of AMPAR MPR in fear memory formation.

\section{MATERIALS AND METHODS}

\section{Animals}

Male Sprague Dawley rats (250-300 g) were used in the study (Harlan Laboratories). Rats were housed separately at $22 \pm 2{ }^{\circ} \mathrm{C}$ in a 12-h light/dark cycle, with free access to food and water. The experiments were conducted during the light phase. Behavioral experiments were approved by the University of Haifa Institutional Committee for animal experiments in accordance with National Institutes of Health guidelines.

\section{Fear Conditioning}

Fear conditioning took place in a Plexiglas rodent conditioning chamber with a metal grid floor (Coulbourn Instruments). Rats were habituated to the training chamber for 15 min 1 day before fear conditioning. On the next day, rats were allowed to acclimate to the conditioning chambers for $5 \mathrm{~min}$ followed by five pairings of a tone (CS; $40 \mathrm{~s}, 5 \mathrm{kHz}$, $78 \mathrm{~dB}$ ) that was co-terminated with a foot shock (US; $0.5 \mathrm{~s}$, $1.3 \mathrm{~mA}$ ). The intertrial interval (ITI) was random with average of $180 \mathrm{~s}( \pm 25 \%)$. Rat groups were tested $2 \mathrm{~h}$ after training for short-term memory (STM) or $24 \mathrm{~h}$ after training for long-term memory (LTM) in a chamber with different floor, light, and odor to diminish the effect of context. Rats were given 5-min acclimation period prior to the memory test and then were presented with 5 tones $(40 \mathrm{~s}, 5 \mathrm{kHz}, 78 \mathrm{~dB})$ with average ITI of $180 \mathrm{~s}( \pm 25 \%)$. For the re-testing experiment, the animals were presented $24 \mathrm{~h}$ after training with $10 \mathrm{CS}$ tones. Behavior was recorded and the video images were transferred to a computer equipped with an analysis program. The percentage of changed pixels between two adjacent 1-s images was used as a measure of activity.

\section{Conditioned Taste Aversion (CTA)}

Rats were water deprived for 3 days and were given water through pipettes (two pipettes containing $10 \mathrm{ml}$ of water each) for $15 \mathrm{~min}$. On the fourth day (conditioning day), animals were microinfused with TAT-MPR(DD), TAT-MPR (AA), or saline into the insular cortex (IC). Thirty minutes after the microinfusion, animals were presented with novel taste $(0.1 \%$ saccharine; CS) instead of water and $40 \mathrm{~min}$ afterwards were injected with $\mathrm{LiCl}(0.15 \mathrm{M}, 2 \%$ body weight; US). For the next 2 days, the animals were presented only with water (two pipettes containing $10 \mathrm{ml}$ ) for $15 \mathrm{~min}$. The following 5 days the animals were presented once each day with both saccharine and water for a multi-choice test (two pipettes with water $10 \mathrm{ml}$ each and two pipettes saccharine $10 \mathrm{ml}$ each). The aversion index was defined as (milliliters of water/(milliliters of water+milliliters of saccharin) $) \times 100$ consumed in the test. Thus, 50 is chance level and the higher the aversive index, the stronger the memory.

\section{Surgical Procedures}

Rats were anesthetized with Ketamine $0.1 \mathrm{ml} / 100 \mathrm{~g}$ and Xylazine $0.06 \mathrm{ml} / 100 \mathrm{~g}$ and restrained in a stereotaxic apparatus (Kopf, USA). Guide stainless-steel cannulas (23 gauge) were implanted bilaterally $2 \mathrm{~mm}$ above the LA (LA coordinates are in reference to bregma: anteroposterior (AP), - 3.0; lateral (L) \pm 5.2 ; and dorsoventral (DV), -8.5 ). Rats in CTA experiments were injected into the IC (AP: +1.2; L: $\pm 5.5 ; \mathrm{DV}:-5.5)$. Rats were given antibiotics (Pen and Strep, Norbrook) and Calmagine (Vetoquinol) for analgesia on surgery day. Rats were given 7 days for recovery before behavioral training.

\section{Microinjection}

The stylus was removed from the guide cannula and a 28-gauge injection cannula, extending $2 \mathrm{~mm}$ from the tip of the guide cannula aimed to the LA or IC, was carefully placed. The injection cannula was connected via PE20 tubing, back filled with saline with a small air bubble separating the saline from the peptide solution, to a $10 \mu \mathrm{l}$ Hamilton micro-syringe, driven by a microinjection pump (PHD 2000, Harvard Apparatus). Solution was injected at a rate of $0.5 \mu \mathrm{l} / \mathrm{min}$. Total volume injected was $0.5 \mu \mathrm{l}$ per LA and $1 \mu \mathrm{l}$ per IC. TAT-MPR(DD) peptide (Ac-YGRKKRRQRRREFCYKSRDEDKRMK-Lys(biotin)NH2), TAT-MPR(AA) peptide (Ac-YGRKKRRQRRREFCYKS RAEAKRMK-Lys(biotin)-NH2), or TAT-control peptide (Ac-YGRKKRRQRRRFEDRSKEYMAACKF-Lys(biotin)-NH2) (GL Biochem) were dissolved in saline at a concentration of $50 \mu \mathrm{g} / \mu \mathrm{l}$. Following injection, the injection cannula was left for an additional $1 \mathrm{~min}$ before withdrawal to minimize dragging of the injected liquid along the injection track.

\section{Histology}

After behavior was completed, rats were decapitated and the brains were quickly removed, placed on dry ice, and stored at $-80^{\circ} \mathrm{C}$ until use. Brains were sliced $(55 \mu \mathrm{m})$ and stained with cresyl violet. Cannula placements were verified. Only rats with cannula tips at or within the boundaries of the BLA or IC were included in the data analysis.

\section{Peptide Localization in the Brain}

Rats were microinjected bilaterally with TAT-MPR(DD), TAT-MPR(AA), or TAT-control peptide $(0.5 \mu \mathrm{l}$ of $50 \mu \mathrm{g} / \mu \mathrm{l}$ peptide at $0.5 \mu \mathrm{l} / \mathrm{min}$ ) and were anesthetized $30 \mathrm{~min}$ later 
using sodium thiopental $1: 1$ in PBS at $0.1 \mathrm{ml}$ per $100 \mathrm{~g}$ rat weight. Animals were perfused intracardially with $\sim 250 \mathrm{ml}$ PBS followed with $250 \mathrm{ml}$ PFA solution $(4 \% \mathrm{w} / \mathrm{v}$ PFA in PBS containing $5 \% \mathrm{w} / \mathrm{v}$ sucrose and $3.3 \times 10^{-4} \%$ of $1 \mathrm{M}$ $\mathrm{NaOH})$. After perfusion, the brains were removed and placed in 25\% PFA solution in PBS and 24\% w/v sucrose for 3 days at $4{ }^{\circ} \mathrm{C}$ until the brain sank to the bottom of the tube. Brains were frozen and sliced at a thickness of $45 \mu \mathrm{m}$. Slices were incubated in cold PBS for $1 \mathrm{~h}$ at RT. Slices were subjected to Alexa Fluor 568-streptavidin diluted 1:2000 in PBS. The slices were left at RT for $1 \mathrm{~h}$ to incubate. Following incubation, slices were washed twice with PBS and once with DAPI $(10 \times)$ diluted 1:5000 in PBS, mounted on slides, and covered with $10 \mu \mathrm{l}$ antifade solution and coverslips.

\section{Immunohistochemistry}

Thirty minutes before fear conditioning, the cannulated animals were microinjected into the LA with TAT-MPR (DD) or TAT-MPR(AA) labeled at the C-terminal with fluorescein isothiocyanate. Two hours after the training, the animals were anesthetized by injection of Ketamine/Xylazine and Isofluoran and transcardially perfused with $\sim 250 \mathrm{ml}$ of cold $0.01 \mathrm{M}$ PBS solution, followed by $250 \mathrm{ml}$ of $4 \%$ paraformaldehyde in $0.01 \mathrm{M}$ PBS containing $5 \%$ sucrose. Brains were excised and postfixed in fixative solution containing $30 \%$ sucrose and $1 \%$ paraformaldehyde in $0.01 \mathrm{M}$ PBS for $48 \mathrm{~h}$ at $4{ }^{\circ} \mathrm{C}$. After postfixation, brains were frozen in $-80^{\circ} \mathrm{C}$ until sectioning. Forty-micrometer brain sections were sliced with a cooled cryostat (Leica, CM1900). Slices were washed with $0.01 \mathrm{M}$ PBS and then blocked for $1 \mathrm{~h}$ at room temperature with $0.01 \mathrm{M}$ PBS containing 3\% BSA. Sections were then incubated overnight at $4{ }^{\circ} \mathrm{C}$ with the antiGluA1, anti-GluA2, or anti-GluA4 primary antibodies that recognize the extracellular portion of the receptors (1:200; Alomone Labs, Israel) in $0.01 \mathrm{M}$ PBS containing 1\% BSA. After three washes in $0.01 \mathrm{M}$ PBS, the slices were subjected to Alexa-568 anti-rabbit secondary antibody (1:500 Molecular Probes) in $0.01 \mathrm{M}$ PBS for $1.5 \mathrm{~h}$ at room temperature. The slices were then washed twice with PBS $0.01 \mathrm{M}$ and mounted on Super Frost-coated slides with Slow Fade antifade medium (Invitrogen). Slides were kept in the dark before image acquisition and analysis. Images were taken with a Zeiss LSM-510 confocal microscope.

\section{Statistics}

Data were analyzed with repeated-measures ANOVA with an $\alpha$ level of 0.05 using the PASW statistics 20 .

\section{RESULTS}

\section{GluA1-MPR Competing Peptide in LA Impairs Long- Term Fear Conditioning Memory Formation}

The effect of TAT-MPR(DD) in LA on long-term fear conditioning memory formation was tested. Microinjection of TAT-MPR(DD) peptide into LA led to its internalization into cells when tested $30 \mathrm{~min}$ later (Figure 1b). Figure 1c shows that in LA neuronal surface expression of GluA1 levels (antibodies against the extracelluar portion of GluA1) $2 \mathrm{~h}$ after fear conditioning training is reduced in neurons that contain the TAT-MPR(DD) peptide compared with neurons that do not contain the peptide. Freezing during training was not affected by microinjection of the TAT-MPR(DD) $30 \mathrm{~min}$ before fear conditioning $\left(\mathrm{F}_{(2.713)}=0.0 .147, p>0.9\right)$ as well as the treatment $\times$ tone trial interaction during training $\left(F_{(1)}=0.0001, p>0.9\right.$; Figure 1d) indicating that the TATMPR(DD) peptide does not affect freezing per se, foot shock sensitivity, and CS and US processing in the LA. Microinjection of TAT-MPR(DD) $(n=12)$ into LA 30 min before fear conditioning significantly and markedly impaired fear conditioning LTM when compared with saline $(n=9)$ $\left(\mathrm{F}_{(1)}=16.909, p<0.002\right.$; Figure 1e) (see Figure 5 for cannula placements). The treatment $\times$ tone trial interaction was not significant $\left(\mathrm{F}_{(4)}=0.432, p>0.7\right)$ indicating that the rate of changes in fear responses along the trials was similar in all the groups. Freezing of animals during the pre-CS was not significantly different $(p>0.1)$ indicating that the context has no effects on freezing. Together these results show the GluA1-MPR is needed for fear LTM.

\section{GluA1-MPR Competing Peptide in LA Impairs Short-Term Fear Conditioning Memory Formation}

To study whether the GluA1 MPR is needed for STM formation, we microinjected TAT-MPR(DD) peptide into LA 30 min before fear conditioning and tested for STM $2 \mathrm{~h}$ after training. Freezing during training was not affected by the treatment $\left(\mathrm{F}_{(1)}=1.903, p>0.18\right)$ (Figure 1f). The treatment $\times$ tone trial interaction for freezing during training was not significant $\left(\mathrm{F}_{(1.002)}=1.914, p>0.18\right)$. Figure $1 \mathrm{~g}$ shows that fear STM is significantly impaired by the TATMPR(DD) peptide $(n=11)$ when compared with animals microinjected with saline $(n=6)\left(\mathrm{F}_{(1)}=11.801, p<0.005\right)$ (see Figure 5 for cannula placements). The treatment $\times$ tone trial interaction was not significant $\left(\mathrm{F}_{(2.695)}=0.9, p>0.4\right)$. Freezing during pre-CS was not significantly different $(p>0.7)$ between the animals. Cumulatively, these results show that the GluA1-MPR is needed for fear STM.

\section{Fear Conditioning Memory Retrieval is not Affected by GluA1-MPR Competing Peptide}

TAT-MPR(DD) affects both STM and LTM memory formation. To further exclude the possibility that TATMPR(DD) peptide affects transmission, we explored its effects on memory retrieval. Memory retrieval requires intact transmission in LA (eg, Muller et al, 1997). We microinjected the TAT-MPR(DD) peptide $30 \mathrm{~min}$ before LTM test and studied its effects on retrieval of memory. Figure 2 shows that the TAT-MPR(DD) peptide $(n=13)$ had no significant effect on fear memory compared with saline $(n=8)$ when injected before memory test $\left(\mathrm{F}_{(1)}=0.329, p>0.5\right)$ (see Figure 5 for cannula placements). The treatment $\times$ tone trial interaction was not significant $\left(\mathrm{F}_{(2.634)}=0.22, p>0.8\right)$. These results show that TAT-MPR(DD) competing peptide in LA has no effect on fear memory retrieval. To further explore the long-term effects of the peptide, animals were microinjected with the TAT-MPR(DD) $(n=4)$ or saline $(n=3)$ before retrieval (test 1 ) and were retested again $24 \mathrm{~h}$ later (test 2 ). Freezing during the second test was reduced in all the groups, and there were no significant differences in freezing between the groups in the second test $\left(\mathrm{F}_{(1)}=1.769, p>0.2\right.$; 


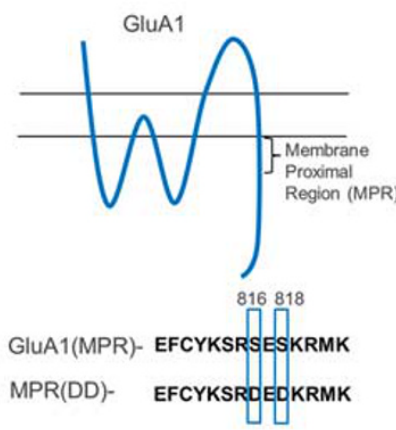

b

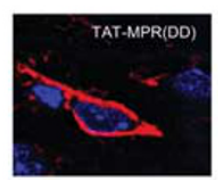

C

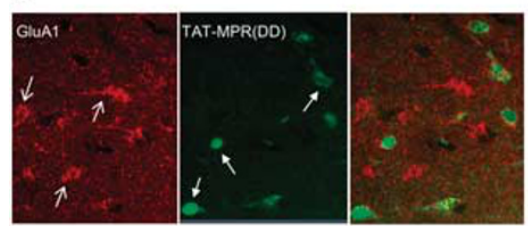

d
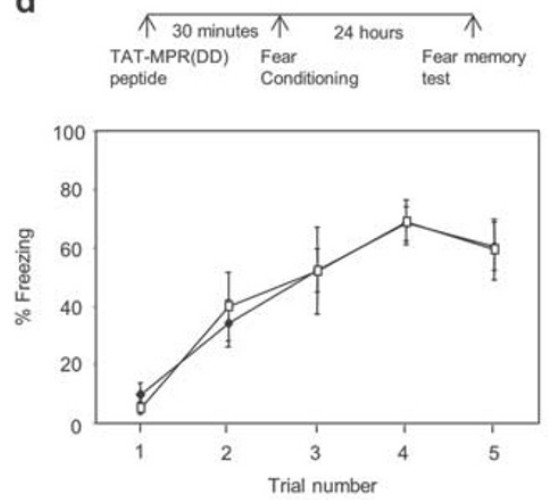

f
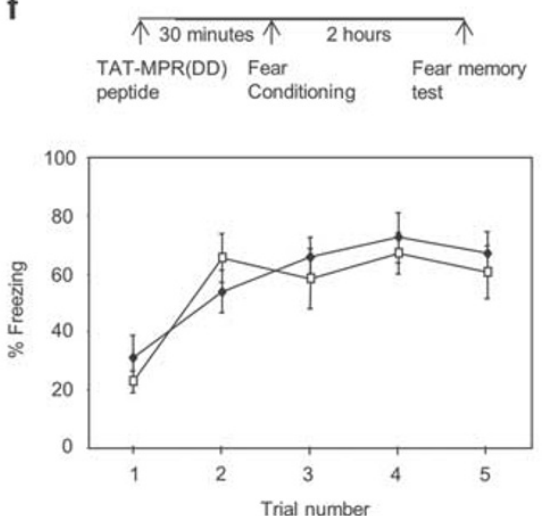

e

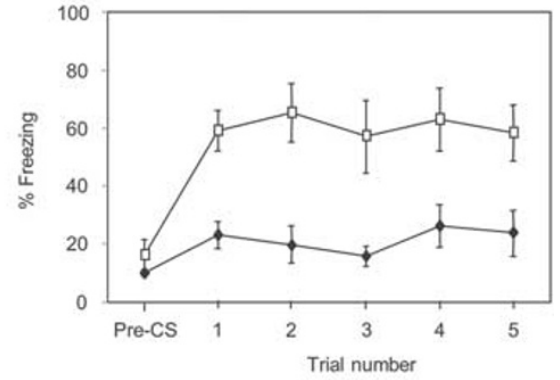

g

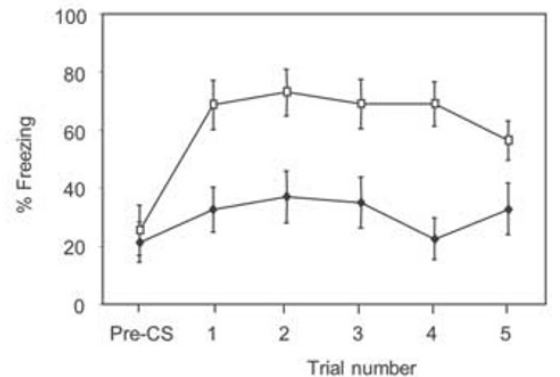

Figure I GluAI-MPR in LA is essential for long- and short-term fear memory formation. (a) The MPR(DD) peptide is derived from the MPR region of GluAI where the serines at position 816 and 818 are replaced with aspartates (highlighted with squares). (b) Microinjection of biotin-labeled TAT-conjugated MPR(DD) into the LA ( $50 \mu \mathrm{g} / \mu \mathrm{l}, 0.5 \mu \mathrm{l}$ per LA) led to its insertion into cells when tested 30 min later as detected by the Alexa Fluor $568-$ streptavidin (red) labeling (blue -DAPI staining). (c) Rats were microinjected with fluorescent (FITC)-labeled TAT-MPR(DD) into LA 30 min before fear conditioning. Two hours after training, surface GluAI receptors and peptide containing neurons were monitored. Antibodies were against the extracellular portion of the GluA I to detect surface-expressing receptor. As seen, the surface expression of GluAI (open arrows) $2 \mathrm{~h}$ after fear conditioning training is reduced in neurons that contain the TAT-MPR(DD) peptide compared with neurons that do not contain the peptide (closed arrows). (d) Freezing throughout the tone presentations during training of the same animals as in panel (e) was analyzed. There is no significant difference between animals injected with TAT-MPR(DD) peptide and rats injected with saline $\left(F_{(I)}=0.000 \mathrm{I}, p>0.9\right)$. (e) Microinjection of the TAT-MPR(DD) peptide into LA (50 $\mu g / \mu l, 0.5 \mu \mathrm{l}$ per $\left.L A ; n=\mid 2\right) 30 \mathrm{~min}$ before fear conditioning significantly impaired long-term fear memory formation tested $24 \mathrm{~h}$ after training when compared with saline-injected rats $(0.5 \mu \mathrm{l}$ saline per $\mathrm{LA}$; $n=9)\left(F_{(I)}=16.909, p<0.002\right)$. (f) Freezing throughout the tone presentations during training of the same animals in panel $(g)$ was analyzed. There is no significant difference between animals injected with TAT-MPR(DD) peptide and rats injected with saline $\left(F_{(I)}=1.903, p>0.18\right)$. (g) Microinjection of the TATMPR(DD) peptide $(50 \mu \mathrm{g} / \mu \mathrm{l}, 0.5 \mu \mathrm{l}$ per $L A ; n=1 \mathrm{I})$ into LA 30 min before fear conditioning significantly impaired short-term fear memory formation tested $2 \mathrm{~h}$ after training when compared with saline-injected rats $(0.5 \mu \mathrm{l}$ saline per $L A n=6)\left(F_{(I)}=|1.80|, p<0.005\right)$. $\square$, Saline; $>$, TAT-MPR(DD).

no interaction $\left.\mathrm{F}_{(1.724)}=1.1, p>0.3\right)$, indicating that there is no long-term effects of the TAT-MPR(DD) on subsequent fear memory tests.

\section{MPR(AA) Peptide in LA Impairs Long-Term Fear Conditioning Memory Formation}

The effect of TAT-MPR(AA) in LA on long-term fear conditioning memory formation was tested. Microinjection of TAT-MPR(AA) peptide into LA led to its internalization into cells when tested $30 \mathrm{~min}$ later (Figure $3 \mathrm{~b}$ ). Figure $3 \mathrm{c}$ (upper panels) shows that in LA neurons surface expression of GluA4 (antibodies against the extracelluar portion of GluA4) $2 \mathrm{~h}$ after fear conditioning training is reduced in neurons that contain the TAT-MPR(AA) peptide compared with neurons that do not. Figure $3 c$ (lower panel) shows colocalization of surface-expressed GluA2 receptors (antibodies against the extracelluar portion of GluA2) and TAT-MPR(AA) peptide, indicating that in these neurons the TAT-MPR(AA) peptide was not effective in reducing surface GluA2. Freezing during training was not affected by microinjection of the TAT-MPR(AA) $30 \mathrm{~min}$ before fear conditioning $\left(\mathrm{F}_{(4)}=0.649, p>0.6\right.$; Figure $\left.3 \mathrm{~d}\right)$. The treatment $\times$ tone trial interaction during training was not significant $\left(\mathrm{F}_{(1)}=0.291 ; p>0.5\right)$. Microinjection of TAT-MPR(AA) $(n=10)$ into LA 30 min before fear conditioning significantly and markedly impaired fear conditioning LTM when compared with saline $(n=9)\left(\mathrm{F}_{(1)}=9.128\right.$, $p<0.009$ ) (Figure $3 \mathrm{e}$ ) (see Figure 5 for cannula placements). The treatment $\times$ tone trial interaction was not significant $\left(\mathrm{F}_{(2.597)}=0.382, p>0.7\right)$. Freezing during pre-CS was not significantly $(p>0.7)$ different between the animals. Together these results show that the TAT-MPR(AA) GluA4-MPR competitive peptide in LA impairs fear LTM 


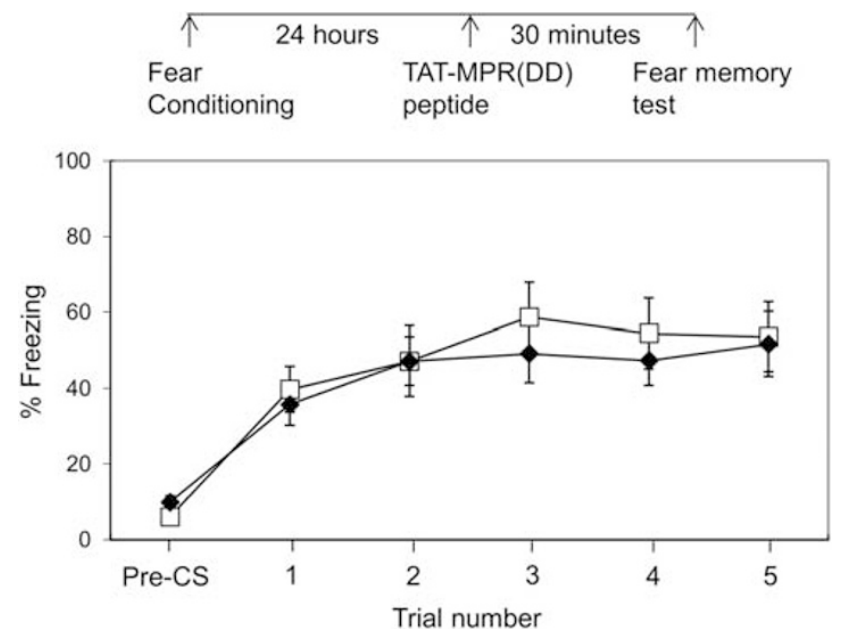

Figure 2 GluAI-MPR is not needed for fear memory retrieval. TAT-MPR (DD) $(50 \mu \mathrm{g} / \mu \mathrm{l}, 0.5 \mu \mathrm{l}$ per LA, $n=13)$ or saline $(0.5 \mu \mathrm{l}$ per $L A, n=8)$ were injected into LA $30 \mathrm{~min}$ before long-term fear conditioning memory test. There was no significant effect on fear memory retrieval between animals injected with the TAT-MPR(DD) peptide when compared with rats injected with saline $\left(F_{(I)}=0.329, p>0.5\right)$. $\square$, Saline; $>$, TAT-MPR(DD).

formation. We also examined the effects of the TAT-MPR (AA) peptide on long-term fear memory retrieval. The TATMPR(AA) injected 30 min before fear memory test had no effect $(n=6)$ on freezing during test when compared with saline $(n=3)\left(\mathrm{F}_{(1)}=0.082, p>0.7\right)$. The treatment $\times$ tone trial interaction was not significant $\left(\mathrm{F}_{(4)}=0.319, p>0.8\right)$.

\section{MPR(AA) Peptide in LA has no Effect on Short-Term Fear Conditioning Memory Formation}

The effect of TAT-MPR(AA) in LA on short-term fear conditioning memory formation was tested. Freezing during training was not affected by the treatment $\left(\mathrm{F}_{(1)}=0.052\right.$, $p>0.8$; Figure 3f). The treatment $\times$ tone trial interaction during training was not significant $\left(\mathrm{F}_{(2.535)}=1.228, p>0.3\right)$. Microinjection of TAT-MPR(AA) $(n=11)$ into LA did not affect fear conditioning STM when compared with saline $(n=8) \quad\left(\mathrm{F}_{(1)}=0.679 . p>0.4\right.$; Figure 3g) (see Figure 5 for cannula placements). The treatment $\times$ tone trial interaction was not significant $\left(\mathrm{F}_{(2.415)}=0.296, p>0.7\right)$. Freezing during pre-CS was not significantly $(p>0.9)$ different between the animals. Together these results show that the TAT-MPR (AA) GluA4-MPR competitive peptide in LA has no effects on fear STM formation.

\section{Control Peptide Injected into the LA had no Effect on Short- and Long-Term Fear Memory Formation}

To test whether the effects of TAT-MPR(DD) or TAT-MPR (AA) are caused by the injection of a peptide per se, we microinjected a TAT-control peptide into LA and compared its effects with injection of saline. Microinjection of TATcontrol peptide into LA led to its internalization into cells when tested $30 \mathrm{~min}$ later (Figure $4 \mathrm{a}$ ). There is no significant difference between TAT-control peptide $(n=7)$ and salineinjected animals $(n=5)$ when tested for long-term fear memory $\left(\mathrm{F}_{(1)}=0.004, p>0.9\right.$; Figure $4 \mathrm{~b}$ ) (see Figure 5 for cannula placements). The treatment $\times$ tone trial interaction was not significant $\left(\mathrm{F}_{(4)}=0.34, p>0.8\right)$. Microinjection of a TAT-control peptide $(n=9)$ into LA had no significant effect on STM $\left(\mathrm{F}_{(1)}=1.277, p>0.2\right)$ when compared with saline $(n=8)$ (Figure $4 c)$ (see Figure 5 for cannula placements). The treatment $\times$ tone trial interaction was not significant $\left(\mathrm{F}_{(4)}=0.149, p>0.9\right)$. These results show that injection of a peptide per se has no effect on STM or LTM fear memory formation.

\section{Injection of TAT-MPR(DD) or TAT-MPR(AA) into IC has no Effect on Long-Term CTA Memory Formation}

We were interested to study whether AMPAR MPR-DD or MPR-AA are needed for the formation of a different aversive memory. Toward that end, we tested whether rats microinjected with TAT-MPR(DD) or TAT-MPR(AA) into IC (see Figure 5 for cannula placements) can form a long-term CTA memory. In CTA, rats learn to associate between a novel palatable taste (CS; (saccharin)) and gastrointestinal malaise (US) so that when the rats encounter the CS after training they avoid it. We did not detect any changes between the TAT-MPR(DD), TAT-MPR(AA), or saline ( $n=4$ each) injected rats when tested for the CTA 2 days after training for 5 consecutive days $\left(\mathrm{F}_{(2)}=1.242, p>0.3\right)$ (Figure $4 \mathrm{~d}$ ). There is no interaction between the groups along the test days $\left(\mathrm{F}_{(3.598)}=0.433, p>0.7\right)$. These results indicate that the peptides have no non-specific effects on brain faculties needed for memory formation and that the AMPAR-MPR regions are needed for specific behavioral paradigms that include fear conditioning.

\section{DISCUSSION}

Previous studies have shown that GluA1-MPR and GluA4MPR, but not GluA2-MPR, are needed for AMPAR insertion into synapse and neuronal membrane and for synaptic plasticity (Shi et al, 2001; Correia et al, 2003; Boehm et al, 2006; Gomes et al, 2007; Lin et al, 2009; Mitsushima et al, 2011). However, the role of AMPAR-MPR in LTM formation is not known. In this study, we examined whether AMPARMPR is needed for short- and long-term fear memory formation in LA. Toward that end, we utilized MPRcompeting peptide (MPR(DD)) composed of a modified GluA1-MPR site that was shown to impair activitydependent insertion of GluA1 into the synapses and synaptic plasticity (Boehm et al, 2006; Mitsushima et al, 2011) and MPR competitive peptide (MPR-(AA)) derived from GluA4 MPR shown to be essential for GluA4 protein interaction needed for GluA4 insertion into the synapse (Correia et al, 2003; Coleman et al, 2003; Boehm et al, 2006; Gomes et al, 2007).

Our results show that microinjection of TAT-MPR(DD) competing peptide into LA before fear conditioning impaired both long-term and short-term fear memory formation. These results indicate that GluA1-MPR in LA is essential for fear conditioning learning. TAT-MPR(DD) had no effect on freezing during training, indicating that the TAT-MPR(DD) has no effect on transmission needed for tone and shock perception. Consistent with our findings is the observation that MPR(DD) fragment has no effects on 
a

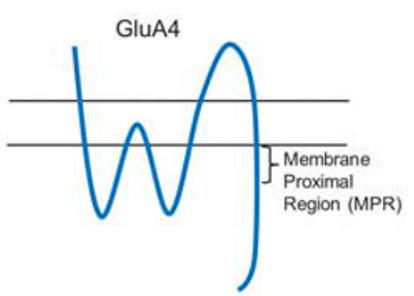

GluA4 MPR(AA)- EFCYKSRAEAKRMK

b

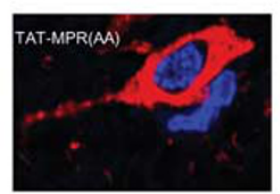

c

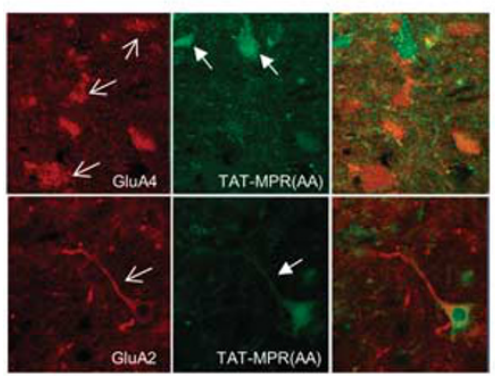

d

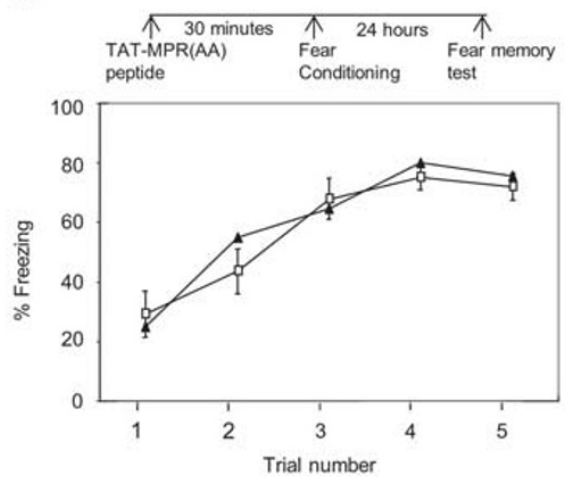

f
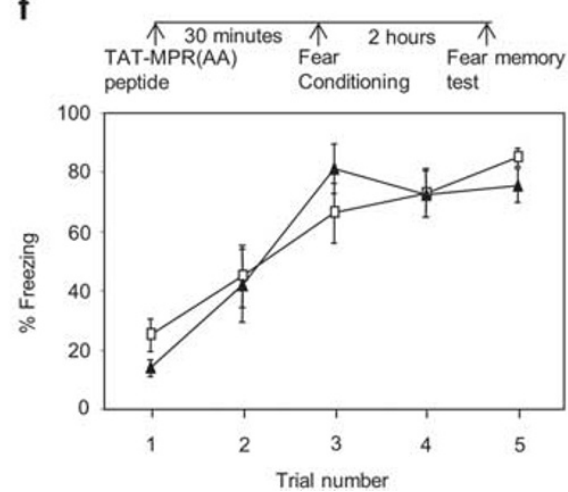

e

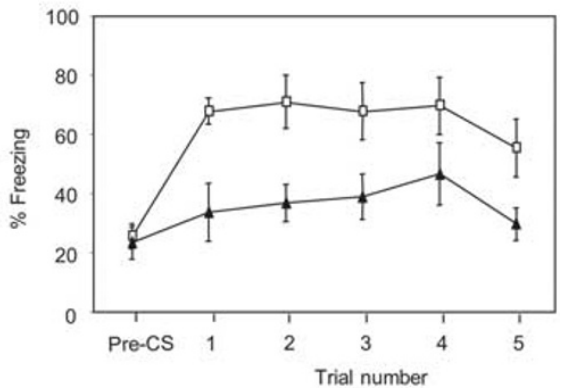

g

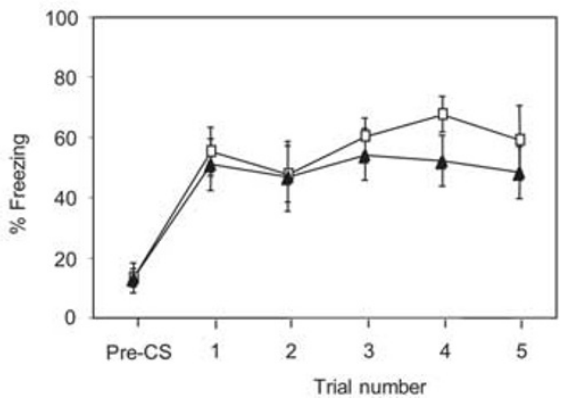

Figure 3 TAT-MPR(AA) in LA impairs long-term but not short-term fear memory formation. (a) The MPR(AA) peptide is derived from the MPR region of GluA4. The GluA4 MPR is different from GluAI MPR region at positions 816 and 818 where the GluA4 contains alanines (highlighted by squares). (b) Microinjection of biotin-labeled TAT-conjugated MPR(AA) into the LA ( $50 \mu \mathrm{g} / \mu \mathrm{l}, 0.5 \mu \mathrm{l}$ per LA) led to its insertion into cells when tested 30 min later as detected by the Alexa Fluor 568-streptavidin (red) labeling (blue -DAPI staining). (c) Rat were microinjected with fluorescent (FITC)-labeled TAT-MPR(AA) into LA 30 min before fear conditioning. Two hours after training, surface expression of the GluA4 (upper panels) or GluA2 (lower panels) receptors was monitored. We used antibodies against the extracellular portion of the GluA4 or GluA2 to detect surface-expressing receptors. As seen, the surface expression of GluA4 (open arrows) $2 \mathrm{~h}$ after fear conditioning training is reduced in neurons that contain the TAT-MPR(AA) peptide (closed arrows) compared with neurons that do not contain the peptide. The GluA2 (open arrow) is expressed at the surface of neurons that contain the TAT-MPR(AA) peptide (closed arrow), indicating that the peptide is not effective in these neurons. (d) Freezing throughout the tone presentations during training of the same animals as in panel (e) was analyzed. There is no significant difference between animals injected with TAT-MPR(AA) peptide and rats injected with saline $\left(F_{(4)}=0.649, p>0.6\right)$. (e) Microinjection of the TAT-MPR(AA) peptide $(50 \mu \mathrm{g} / \mu \mathrm{l}, 0.5 \mu \mathrm{l}$ per LA $n=10)$ into LA 30 min before fear conditioning significantly impaired long-term fear memory formation tested $24 \mathrm{~h}$ after training when compared with saline-injected rats $(0.5 \mu \mid$ saline per $L A n=9)\left(F_{(I)}=9.128\right.$, $p<0.009$ ). (f) Freezing throughout the tone presentations during training of the same animals as in panel (g) was analyzed. There is no significant difference between animals injected with TAT-MPR(AA) peptide and rats injected with saline $\left(F_{(2.535)}=1.228, p>0.3\right)$. (g) Microinjection of the TAT-MPR(AA) peptide $(50 \mu \mathrm{g} / \mu \mathrm{l}, 0.5 \mu \mathrm{l}$ per LA $n=\mathrm{II})$ into LA 30 min before fear conditioning had no significant effect on short-term fear memory formation tested $2 \mathrm{~h}$ after training when compared with saline-injected rats $(0.5 \mu$ saline per $L A n=8)\left(F_{(I)}=0.679 . p>0.4\right)$. $\square$, Saline; $\boldsymbol{\Delta}$, TAT-MPR(AA).

AMPA and NMDA receptors-mediated basal transmission in hippocampal neurons (Boehm et al, 2006; Mitsushima et al, 2011). An additional observation that supports the indications that TAT-MPR(DD) has no effects on synaptic transmission and tone perception is its inability to affect memory retrieval when injected into LA $30 \mathrm{~min}$ before LTM test. Synaptic transmission in LA was shown to be essential for fear memory retrieval (Muller et al, 1997).

Microinjection of TAT-MPR-(AA) peptide into the LA impaired long-term fear memory formation. However, TATMPR (AA) in LA had no effect on short-term fear conditioning memory. These results show that in contrast to the MPR of GluA1 the GluA4 MPR is not needed for learning and memory acquisition but is needed for the consolidation of STM into LTM. TAT-MPR(AA) had no effect on freezing during training indicating that the TATMPR(AA) has no effect on transmission needed for tone and shock perception (see above). The MPR(AA) is derived from the GluA2/4 subunits. MPR(AA) peptide interacts with proteins needed for GluA4 insertion into the synapse (eg, PKC $\gamma$-Correia et al, 2003; Gomes et al, 2007; 4.1 proteinColeman et al, 2003) and mutations of the alanines to serines (816 and 818) in this GluA4 MPR region abolish GluA4 trafficking into the synapse (Boehm et al, 2006). In contrast, GluA2-MPR is not needed for the insertion of GluA2 into the synapse (Shi et al, 2001), and mutations at this region have no effect on GluA2 insertion (Boehm et al, 2006). GluA2 that contains only a similar MPR(AA) fragment in its C-terminal 
a
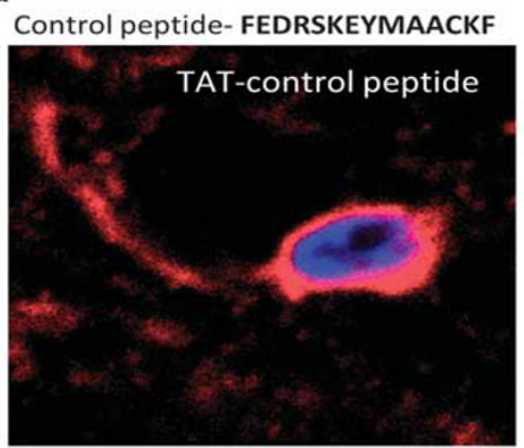

C
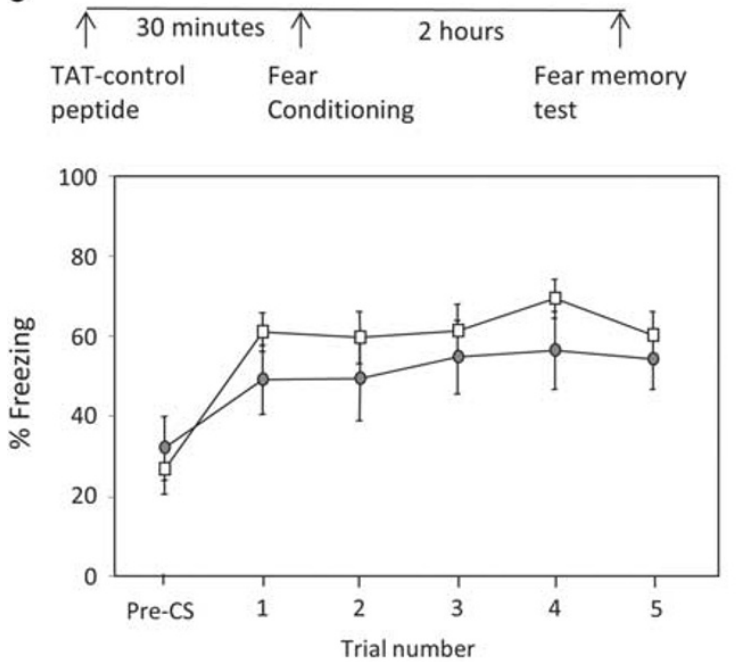

b
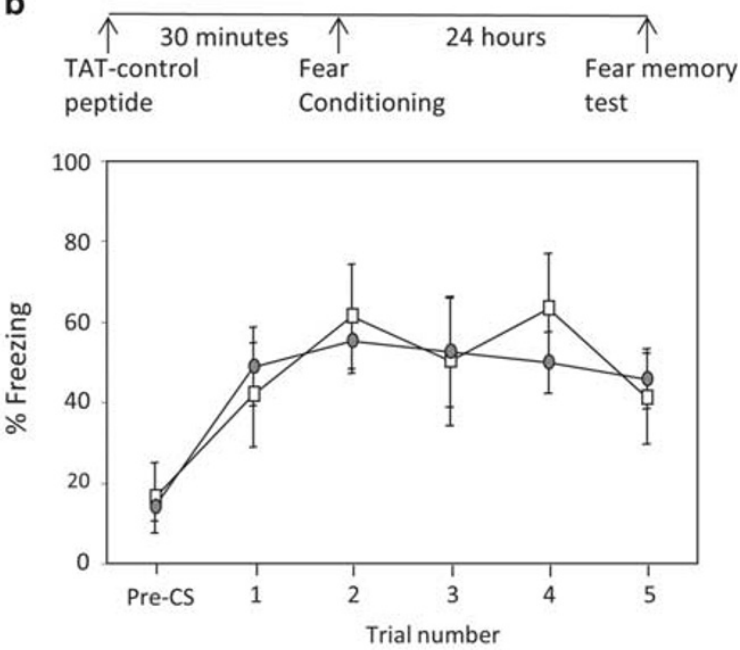

d

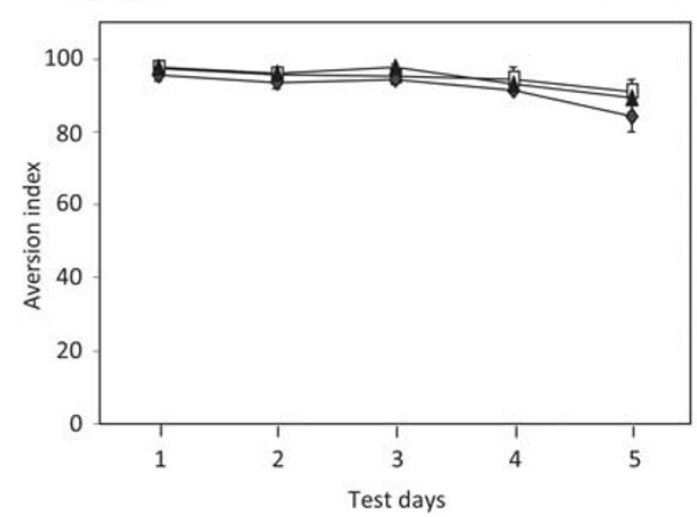

Figure 4 TAT-control peptide in LA has no effect on short- and long-term fear conditioning memory and TAT-MPR(DD) and TAT-MPR(AA) in IC has no effect on long-term CTA memory formation. (a) The control peptide sequence is shown. Microinjection of biotin-labeled TAT-conjugated control peptide into the LA ( $50 \mu \mathrm{g} / \mu \mathrm{l}, 0.5 \mu \mathrm{l}$ per LA) led to its insertion into cells when tested $30 \mathrm{~min}$ later as detected by the Alexa Fluor 568-streptavidin (red) labeling (blue -DAPI staining). (b) Microinjection of the TAT-control peptide $(50 \mu \mathrm{g} / \mu \mathrm{l}, 0.5 \mu \mathrm{l}$ per $L A n=7)$ into LA 30 min before fear conditioning had no significant effects on long-term fear memory formation tested $24 \mathrm{~h}$ after training when compared with saline $(0.5 \mu l$ saline per $L A n=5)\left(F_{(I)}=0.004, p>0.9\right)$. (c) Microinjection of the TAT-control peptide $(50 \mu \mathrm{g} / \mu \mathrm{l}, 0.5 \mu \mathrm{l}$ per $L A n=9)$ into LA 30 min before fear conditioning had no significant effects on short-term fear memory formation tested $2 \mathrm{~h}$ after training when compared with saline-injected rats $(0.5 \mu \mathrm{l}$ saline per $L A n=8)\left(F_{(I)}=1.277, p>0.2\right)$. $\square$, Saline; - TAT-control peptide. (d) CTA long-term memory in rats that were microinjected with the TAT-MPR(DD), TAT-MPR(AA), or saline into the IC is not significantly different between the groups $\left(F_{(2)}=1.242, p>0.3\right)$. $\square$, saline;

, TAT-MPR(DD); $\triangle$, TAT-MPR(AA)

(MPR(AA) peptide sequence and an additional one amino acid) do not interact with intracellular proteins that regulate GluA2 synaptic incorporation, retention, and removal from the synapse (eg, AP2 and GRIP; Lee et al, 2002).

As described above, the MPR(DD) is needed for activitydependent GluA1-containing AMPAR trafficking into the membrane and for LTP (Boehm et al, 2006; Mitsushima et al, 2011). Our observation is thus consistent with the findings showing that fear conditioning drives GluAl-containing AMPA receptors into synapses in LA neurons (Rumpel et al, 2005; Yeh et al, 2006) and that short- and long-term fear conditioning memory are impaired if GluAl-containing AMPAR insertion is blocked (Rumpel et al, 2005). Moreover, similarly to our findings, GluA1-AMPAR trafficking inhibition in LA has no effect on freezing during training (Rumpel et al, 2005).

GluA4-containing AMPAR can also be delivered into the synapse after neuronal conditioning (eg, Mokin and Keifer, 2004) and activity (eg, Zhu et al, 2000). In vitro model of eyeblink classical conditioning, where a weak electrical stimulation of the auditory nerve (the 'tone' CS) is paired with a strong stimulation of the trigeminal nerve (the 'air puff US), leads to marked increased synaptic delivery of GluA4-containing AMPAR when compared with nonassociative stimulation (random presentations of CS and US) (eg, Mokin and Keifer, 2004).

Mitsushima et al (2011) have shown that the MPR-DD peptide can block training-driven synaptic AMPAR delivery 
Bregma

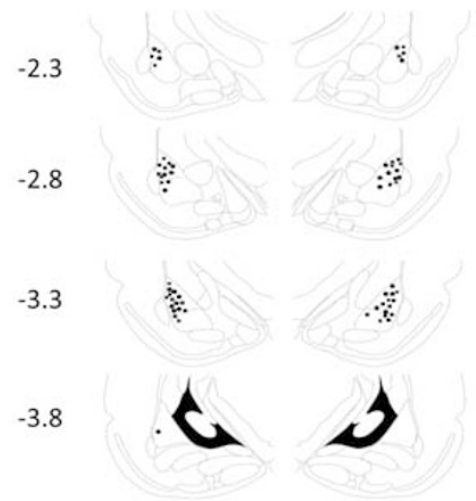

d

Bregma

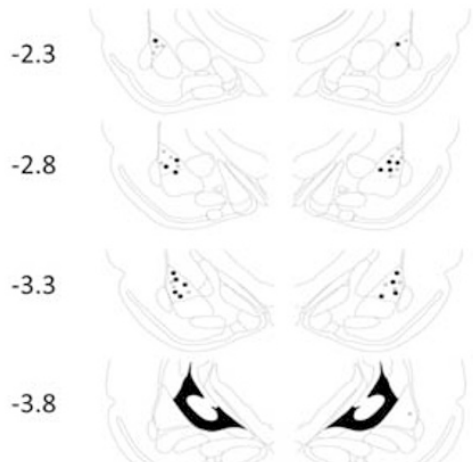

b

Bregma

$-3.3$

$-3.8$

e

Bregma

$-2.3$

$-2.8$

$-3.3$

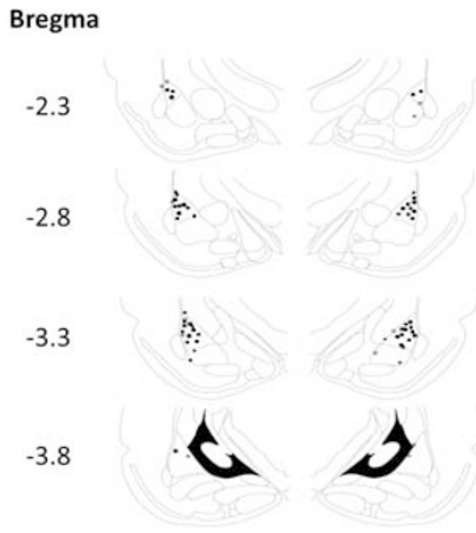

Figure 5 Cannula placements. (a) Cannula tip placements from rats injected with TAT-MPR(DD) peptide, TAT-control peptide, or saline before training tested for LTM; (b) Cannula tip placements from rats injected with TAT-MPR(DD) peptide, TAT-control peptide, or saline before training tested for STM. (c) Cannula tip placements from rats injected with TAT-MPR(DD) peptide, peptide TAT-MPR(AA), or saline before the LTM test. (d) Cannula tip placements from rats injected with TAT-MPR(AA) peptide or saline before training tested for LTM. (e) Cannula tip placements from rats injected with TAT-MPR(AA) peptide or saline before training tested for STM. (f) Cannula tip placements from rats injected TAT-MPR(DD), TAT-MPR(AA), or saline followed by CTA training. $\square$, TAT-MPR(DD) peptide; $X$, TAT-control peptide; $\square$, TAT-MPR(AA) peptide; $\boldsymbol{\bullet}$, saline.

in CA1 neurons. Moreover, hippocampal CA1 GFP-MPR (DD)-expressing rats are impaired in STM of inhibitory avoidance task tested $30 \mathrm{~min}$ after training. LTM effects of the MPR(DD) and MPR(AA) were not examined.

By using a well-established and specific GluA1-MPR competing peptide (Boehm et al, 2006; Lin et al, 2009; Mitsushima et al, 2011), we show that GluA1-MPR has a key role in shortterm and long-term fear memory but not its retrieval. Furthermore, we show that microinjection of a GluA4-MPR protein fragment (Boehm et al, 2006; Correia et al, 2003; Gomes et al, 2007) impairs long-term but not short-term fear memory formation. These results show that, whereas GluA1MPR in LA is needed for fear conditioning learning and memory acquisition, the GluA4-MPR in LA is needed for the consolidation of fear conditioning STM into LTM.

\section{FUNDING AND DISCLOSURE}

There are no competing financial interests in relation to the work described. The study is funded by the National Institute for Psychobiology in Israel.

\section{REFERENCES}

Boehm J, Kang MG, Johnson RC, Esteban J, Huganir RL, Malinow R. (2006). Synaptic incorporation of AMPA receptors during LTP is controlled by a PKC phosphorylation site on GluR1. Neuron 51: 213-225.

Chen K, Merino C, Sigrist SJ, Featherstone DE. (2005). The 4.1 protein coracle mediates subunit-selective anchoring of Drosophila glutamate receptors to the postsynaptic actin cytoskeleton. J Neurosci 25: 6667-6675.

Coleman SK, Cai C, Mottershead DG, Haapalahti JP, Keinänen K (2003). Surface expression of GluR-D AMPA receptor is dependent on an interaction between its C-terminal domain and a 4.1 protein. J Neurosci 23: 798-806.

Correia SS, Duarte CB, Faro CJ, Pires EV, Carvalho AL. (2003). Protein kinase $\mathrm{C}$ gamma associates directly with the GluR4 alphaamino-3-hydroxy-5-methyl-4-isoxazole propionate receptor subunit. Effect on receptor phosphorylation. J Biol Chem 278: 6307-6313.

Davis M, Whalen PJ (2001). The amygdala: vigilance and emotion. Mol Psychiatry 6: 13-34.

Fanselow MS, LeDoux JE (1999). Why we think plasticity underlying Pavlovian fear conditioning occurs in the basolateral amygdala. Neuron 23: 229-232. 
Farb CR, Aoki C, Ledoux JE (1995). Differential localization of NMDA and AMPA receptor subunits in the lateral and basal nuclei of the amygdala: a light and electron microscopic study. J Comp Neurol 362: 86-108.

Granger AJ, Shi Y, Lu W, Cerpas M, Nicoll RA. (2013). LTP requires a reserve pool of glutamate receptors independent of subunit type. Nature 493: 495-500.

Gomes AR, Correia SS, Esteban JA, Duarte CB, Carvalho AL (2007). PKC anchoring to GluR4 AMPA receptor subunit modulates PKC-driven receptor phosphorylation and surface expression. Traffic, (2007) 8: 259-269.

Hebb DO (1949). The Organization of Behavior: a Neuropsychological Theory. Wiley: New York, NY, USANew York, NY, USA.

Johansen JP, Cain CK, Ostroff LE, LeDoux JE. (2011). Molecular mechanisms of fear learning and memory. Cell 147: 509-524.

LeDoux JE (2000). Emotion circuits in the brain. Annu Rev Neurosci 23: $155-184$

Lee SH, Liu L, Wang YT, Sheng M (2002). Clathrin adaptor AP2 and NSF interact with overlapping sites of GluR2 and play distinct roles in AMPA receptor trafficking and hippocampal LTD. Neuron 36: 661-674.

Lin DT, Makino Y, Sharma K, Hayashi T, Neve R, Takamiya K et al (2009). Regulation of AMPA receptor extrasynaptic insertion by 4.1N, phosphorylation and palmitoylation. Nat Neurosci 12: 879-887.

Maren S (2005). Synaptic mechanisms of associative memory in the amygdala. Neuron 47: 783-786.

Mitsushima D, Ishihara K, Sano A, Kessels HW, Takahashi T. (2011). Contextual learning requires synaptic AMPA receptor delivery in the hippocampus. Proc Natl Acad Sci USA 108: 12503-12508.

Mokin M, Keifer J. (2004). Targeting of GLUR4-containing AMPA receptors to synaptic sites during in vitro classical conditioning. Neuroscience 128: 219-228.

Muller J, Corodimas KP, Fridel Z, LeDoux JE (1997). Functional inactivation of the lateral and basal nuclei of the amygdala by muscimol infusion prevents fear conditioning to an explicit conditioned stimulus and to contextual stimuli. Behav Neurosci 111: 683-691.
Nedelescu H, Kelso CM, Lázaro-Muñoz G, Purpura M, Cain CK, Ledoux JE et al (2010). Endogenous GluR1-containing AMPA receptors translocate to asymmetric synapses in the lateral amygdala during the early phase of fear memory formation: an electron microscopic immunocytochemical study. J Comp Neurol 518: 4723-4739.

Ota KT, Monsey MS, Wu MS, Schafe GE. (2010). Synaptic plasticity and NO-cGMP-PKG signaling regulate pre- and postsynaptic alterations at rat lateral amygdala synapses following fear conditioning. PLoS One 5: e11236.

Radley JJ, Farb CR, He Y, Janssen WG, Rodrigues SM, Johnson LR et al (2007). Distribution of NMDA and AMPA receptor subunits at thalamo-amygdaloid dendritic spines. Brain Res 1134: 87-94.

Rodrigues SM, Schafe GE, LeDoux JE (2004). Molecular mechanisms underlying emotional learning and memory in the lateral amygdala. Neuron 44: 75-91.

Rumpel S, LeDoux J, Zador A, Malinow R (2005). Postsynaptic receptor trafficking underlying a form of associative learning. Science 308: 83-88.

Sah P, Faber ES, Lopez De Armentia M, Power J (2003). The amygdaloid complex: anatomy and physiology. Physiol Rev 83: 803-834.

Shi S, Hayashi Y, Esteban JA, Malinow R. (2001). Subunit-specific rules governing AMPA receptor trafficking to synapses in hippocampal pyramidal neurons. Cell 105: 331-343.

Schafe GE, Nader K, Blair HT, LeDoux JE (2001). Memory consolidation of Pavlovian fear conditioning: a cellular and molecular perspective. Trends Neurosci 24: 540-546.

Schwarze SR, Ho A, Vocero-Akbani A, Dowdy SF. (1999). In vivo protein transduction: delivery of a biologically active protein into the mouse. Science 285: 1569-1572.

Shen L, Liang F, Walensky LD, Huganir RL. (2000). Regulation of AMPA receptor GluR1 subunit surface expression by a $4.1 \mathrm{~N}-$ linked actin cytoskeletal association. J Neurosci 20: 7932-7940.

Yeh SH, Mao SC, Lin HC, Gean PW (2006). Synaptic expression of glutamate receptor after encoding of fear memory in the rat amygdala. Mol Pharmacol 69: 299-308.

Zhu JJ, Esteban JA, Hayashi Y, Malinow R (2000). Postnatal synaptic potentiation: delivery of GluR4-containing AMPA receptors by spontaneous activity. Nat Neurosci 3: 1098-1106. 